\title{
How to increase share of product-related services in revenue? Strategy towards servitization
}

\author{
Ugljesa Marjanovic ${ }^{1 \text { [0000-0002-8389-6927] }}$, Bojan Lalic ${ }^{\text {[0000-0002-2202-9352] }}$, Vidosav \\ Majstorovic ${ }^{3[0000-0001-9534-8461]}$, Nenad Medic ${ }^{4[0000-0002-4914-334 X]}$, Jasna Prester ${ }^{5[0000-0003-}$ \\ 3027-841X] , Iztok Palcic ${ }^{6[0000-0001-5981-0209] ~}$ \\ ${ }^{1}$ University of Novi Sad, Faculty of Technical Sciences, Novi Sad, Serbia \\ umarjanoduns.ac.rs \\ ${ }^{2}$ University of Novi Sad, Faculty of Technical Sciences, Novi Sad, Serbia \\ blaliceuns.ac.rs \\ ${ }^{3}$ University of Belgrade, Department for Production Engineering, Belgrade, Serbia \\ vidosav.majstorovicesbb.rs \\ ${ }^{4}$ University of Novi Sad, Faculty of Technical Sciences, Novi Sad, Serbia \\ nenad.mediceuns.ac.rs \\ ${ }^{5}$ University of Zagreb, Faculty of Economics, Zagreb, Croatia \\ jpresterdefzg.hr \\ ${ }^{6}$ University of Maribor, Faculty of Mechanical Engineering, Maribor, Slovenia \\ iztok.palcic@um.si
}

\begin{abstract}
The process of creating value by adding services to product offerings, or servitization, has flourished in recent years. Manufacturing companies increasingly produce and provide services along with or instead of their traditional physical products. The provision of product-related services in emerging economies has been neglected and can tremendously improve understanding of service growth, especially in the field of billing. The aim of this study is to examine is it worthwhile for the manufacturing companies in transition countries to offer product-related services and what strategy should they pursue to build service business model. Our analysis used the Croatian, Serbian and Slovenian dataset from the European Manufacturing Survey conducted in 2015. Empirical results revealed that in manufacturing companies in transition countries product-related services can significantly increase share of revenue. Results indicate that management in manufacturing companies should directly invoice software development and revamping, and indirectly installation, and design, as productrelated service to maximize firm's turnover and create a service business model.
\end{abstract}

Keywords: Product-related services, Turnover, EMS.

\section{Introduction}

The process of creating value by adding services to product offerings [1], or servitization, has flourished in recent years [2]. Manufacturing companies increasingly produce and provide services along with or instead of their traditional physical products [3]. A notable reason for this movement is that the concept of servitization could en- 
hance the competitiveness of a manufacturing company while simultaneously advancing economic conditions by higher share of turnover from selling services [1], [2]. Vast majority of manufacturers appear on the market as service providers [4]. Typical examples of the services provided include installation and training, after-sales services (i.e. product repair and maintenance, customer support and recycling), software development, remote support and modernization [5].

Services play a key role in developed economies [3], but in many transition countries the product related services are still in its infancy and present challenge for many manufacturing companies [6]. For a comprehensive analysis of servitization it seems therefore necessary to look at particular product-related service measuring the impact of services on performance of firms (i.e. turnover) [7]. Studies that deal with the assessment of whether adding additional services improves the financial performance of the firm, are scarce and more empirical research is needed in this area [8].

The aim of this study is to examine is it worthwhile for the manufacturing companies in three transition countries (i.e. Croatia, Serbia, Slovenia) to offer product related services and what billing strategy should they pursue: (i) service directly invoiced or (ii) indirectly (included in the product price).

\section{Background and related work}

\subsection{Servitization}

Servitization has become one of the most notable trend in recent years, and has been reflected in the changing structure of many advanced national economies, where services now account for the majority of national output [9]. Early studies reported that firms were adding service to their offering as a means of increasing competitiveness, turnover, and market power [1]. Servitization has evolved from 'goods or services' to 'goods and services'. Moreover, servitization involves more than just provision of more extensive services [10]. It involves firms' evolution in terms of specialization, vertical, horizontal and systematic integration [11]. This is seen as an enabler for value creation by blending services into overall strategies of the company [8]. Academics are almost unanimous in suggesting to product manufacturers to integrate services into their core product offerings since they can increase revenue, achieve higher margins, and accomplish stable source of income [12]. However, the provision of product-related services in emerging economies has been neglected and can tremendously improve our understanding of service growth [8], [13], especially in the field of billing [12].

In describing the service elements provided by manufacturing firms, several labels are used in the literature: industrial services, service strategy in manufacturing, product-related services, product-services, or after-sales services [12]. Focus of this paper is on product-related services, where business model is mainly oriented towards sales of products with additional service offerings [14]. Product-related services can serve as a differentiating characteristic which distinguishes firms within the same market. The distinctive strategy pattern is the ability of these firms to offer their customers unique problem solutions, integrating professional services and innovative products 
[7]. Most of the studies that deals with servitization are focusing on developed economies, while research in developing countries (e.g. Croatia, Serbia, Slovenia) are being neglected. Hence, focus on the specific situation of manufacturing companies in emerging economies is needed to compare to developed economies.

\subsection{Research questions}

Based on literature review, the following research questions were proposed in attempt to identify the different effects of product-related services on manufacturing's firm performance:

- RQ1: Which product-related services increase share of revenue, when directly invoiced?

- RQ2: Which product-related services increase share of revenue, when indirectly invoiced (included in the product price)?

Figure 1 depicts the proposed model for our research questions. Product-related services presented in the model are identified based on exploratory interviews with practitioners and group discussions with experts in the field. All European Manufacturing Survey (EMS) consortium members were involved in this process, which resulted with a universal list of services which is transversal so that all manufacturing sectors can apply it indifferently of the product offered. Consequently, these productrelated services were included in the EMS questionnaire. In the same manner, share of revenue was defined as the share of company revenue in the market [7], [15].

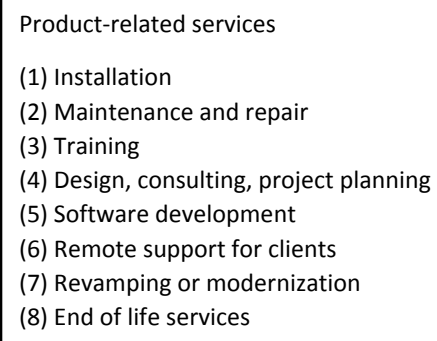

Fig. 1. - Proposed model

\section{$3 \quad$ Data and methodology}

Our analysis used Croatian, Serbian, and Slovenian dataset from the EMS conducted in 2015. Each survey has been carried out based on a proportionally size- and industry-based stratified random sample. Tables 1 and 2 depict the sample distribution across the participating European countries. EMS is a survey on the manufacturing strategies, the application of innovative organizational and technological concepts in production, and questions of servitization in European manufacturing industry [16]- 
[18]. The survey was conducted among manufacturing firms (NACE Rev 2 codes from 10 to 33) having at least 20 employees. The dataset includes 474 firms of all manufacturing industries. About $33.1 \%$ of the firms in the sample are small firms between 20 and 49 employees, another $50.6 \%$ of the firms have between 50 and 249 employees, and $16.3 \%$ of the firms have more than 250 employees. The largest industry in the sample is the manufacture of fabricated metal products (NACE 25; 19.2\%), followed by manufacture of food products (NACE 10;12.9\%) and manufacture of machinery and equipment n.e.c. (NACE $28 ; 9.4 \%$ ).

Tables 1 and 2 show that all constituting national samples of EMS have a reasonable representation for all firm sizes and a fair coverage of all manufacturing industries. The comparison between the firm size distribution of the subsamples of Croatian, Serbian, and Slovenian and the rest of EMS countries (e.g. Germany, Spain, Austria, the Netherlands) data shows no significant size bias. For all sub-samples, no significant differences compared to the rest of EMS countries data are revealed.

To analyze the relationships between product-related services and firm's revenue we employed a multivariate data analyzes.

Table 1. EMS database - distribution of firms by country and size

\begin{tabular}{|c|c|c|c|c|c|}
\hline & \multicolumn{2}{|c|}{$\begin{array}{l}\text { Country } \\
\text { sample }\end{array}$} & \multirow{2}{*}{$\begin{array}{c}20 \text { to } 49 \\
\text { employees } \\
\text { n }(\%)\end{array}$} & \multirow{2}{*}{$\begin{array}{c}\text { Firm size } \\
50 \text { to } 249 \\
\text { employees } \\
\text { n }(\%)\end{array}$} & \multirow{2}{*}{$\begin{array}{c}250 \text { and more } \\
\text { employees } \\
\text { n }(\%)\end{array}$} \\
\hline & $\%$ & $\mathrm{n}$ & & & \\
\hline Croatia & 21.9 & 104 & $31(29.8)$ & $47(45.2)$ & $26(25.0)$ \\
\hline Serbia & 59.1 & 280 & 107 (38.2) & $141(50.4)$ & $32(11.4)$ \\
\hline Slovenia & 19.0 & 90 & $19(21.1)$ & $52(57.8)$ & $19(21.1)$ \\
\hline Total & 100.0 & 474 & & & \\
\hline
\end{tabular}

Table 2. Classification on manufacturing sectors according to share on total sample

\begin{tabular}{llc}
\hline $\begin{array}{l}\text { NACE } \\
\text { Rev. 2 }\end{array}$ & \multicolumn{1}{c}{ Manufacturing industry } & $\begin{array}{c}\text { Share on total } \\
\text { sample (\%) }\end{array}$ \\
\hline 25 & Manufacture of fabricated metal products, except machinery & and \\
& equipment & 19.2 \\
10 & Manufacture of food products & 12.9 \\
28 & Manufacture of machinery and equipment n.e.c. & 9.4 \\
22 & Manufacture of rubber and plastic products & 8.4 \\
27 & Manufacture of electrical equipment & 5.7 \\
23 & Manufacture of other non-metallic mineral products & 5.3 \\
13 & Manufacture of textiles & 4.3 \\
29 & Manufacture of motor vehicles, trailers and semi-trailers & 4.3 \\
14 & Manufacture of wearing apparel & 4.3 \\
18 & Printing and reproduction of recorded media & 3.9 \\
31 & Manufacture of furniture & 3.5 \\
& Others & 18.8 \\
\hline
\end{tabular}




\section{$4 \quad$ Results and Discussion}

Table 2 presents two different regression models, for dependent variable (share of turnover), used to test research questions.

Table 3. - Results of two different regression models

\begin{tabular}{|c|c|c|c|}
\hline \multicolumn{2}{|l|}{ Product-related services } & RQ1 & RQ2 \\
\hline \multicolumn{2}{|l|}{ Installation } & -.050 & $.923^{* * * *}$ \\
\hline \multicolumn{2}{|l|}{ Maintenance and repair } & .141 & $-.587^{* * *}$ \\
\hline \multicolumn{2}{|l|}{ Training } & .228 & $-.973^{* * *}$ \\
\hline \multicolumn{2}{|l|}{ Design, consulting, project planning } & .013 & $.199^{* * * *}$ \\
\hline \multicolumn{2}{|l|}{ Software development } & $.299^{* *}$ & -.027 \\
\hline \multicolumn{2}{|l|}{ Remote support for clients } & -.281 & -.220 \\
\hline \multicolumn{2}{|l|}{ Revamping or modernization } & $.226 * *$ & .057 \\
\hline \multirow[t]{5}{*}{ End of life services } & & $.112^{+}$ & .024 \\
\hline & $\mathrm{R}$ & 0.428 & 0.606 \\
\hline & $\mathrm{R}^{2}$ & 0.183 & 0.368 \\
\hline & $\mathrm{F}$ & 8.125 & 20.363 \\
\hline & Sig. & 0.000 & 0.000 \\
\hline
\end{tabular}

Note: ${ }^{* * *} p<0.001 ;{ }^{* *} p<0.01 ;{ }^{*} p<0.05 ;{ }^{+} p<0.1$

In regression model that tests first research question, the overall model was significant, adjusted $\mathrm{R}^{2}=.183, \mathrm{~F}=8.125, \mathrm{p}<.001$. Two predictors had a significant coefficient - Software development $(\mathrm{B}=.299, \mathrm{p}<.01)$ and Revamping or modernization $(\mathrm{B}=.226, \mathrm{p}<.01)$. Therefore, the results for our research question 1 , "Which product-related services increase share of revenue, when directly invoiced?", indicate that manufacturing companies, in transition countries such as Croatian, Serbian, and Slovenian, can significantly increase share of revenue when directly invoicing productrelated services (i.e. software development and revamping or modernization). Therefore, management in manufacturing companies should directly invoice software development and revamping as product-related service to maximize firm's turnover and create a service business model. While it is possible for a firm to provide productrelated services within the context of a manufacturing operation, we found that firms that were directly billing services, such as maintenance and training, had not achieved higher share of turnover. This results are in line with previous studies [12]. It is not clear from our data, however, if the success of the two product-related services is due to the additional managerial focus these organizations received, or if, as we assume, cultural practices of customers in emerging markets are responsible for thwarting the other services investigated in this research (i.e. installation, maintenance, training, design and remote support).

Second regression model that tests research question 2, was also significant, with adjusted $\mathrm{R}^{2}=.368, \mathrm{~F}=20.363$, and $\mathrm{p}<.001$. Installation $(\mathrm{B}=.923, \mathrm{p}<.001)$ and 
Design, consulting, project planning $(\mathrm{B}=.199, \mathrm{p}<.001)$ had a coefficient that are positively and highly significant, thus supporting the idea to include them in the product price when billing to increase share of revenue. This result provides strong backing for managers in the manufacturing companies to indirectly include fees for services, such as installation and design, consulting and project planning, when provided invoices since they can significantly increase share of turnover. However, companies should not indirectly invoice services such as maintenance and repair, and training since they will significantly decrease firm's share of revenue. This does not mean that firms should not increase turnover when offering such services but will struggle to achieve service growth in overall revenue. Our results indicate that manufacturing firms offering maintenance and repair, and training are still more product rather than service-oriented companies.

Based on results, some of the product-related services did not have statistically significant coefficients (i.e. remote support for clients, end of life services). These results imply that personnel responsible for management of product-related services in the manufacturing firms should reconsider their strategy since current business model is not providing a valuable way for reaching higher success. As suggested by Gebauer et al. [19], utilization of services in manufacturing firms represents the challenge, since some manufacturers find it extremely difficult to successfully exploit the potential of an extended service business. Companies should redesign the current service business model or withdraw remote support for clients, and end of life services from its service portfolio.

\section{Conclusion}

This study examines servitization strategies of the manufacturing companies. Consequently, this paper provides theoretical and practical implications on how and in what way product-related services impact a manufacturing firm's revenue structure. Empirical results indicate that product-related service (i.e. Installation, Design, consulting, project planning, Software development, and Revamping) significantly influence firm's share of revenue when invoiced directly and indirectly (included in the product price). The contribution of this research is the ability to offer recent, international and relevant empirical figures about servitization from the three transition countries Croatia, Serbia and Slovenia.

Our sample was collected from all manufacturing industries, and, perhaps due to the industry specificity, results could differ. Also, there are various aspects that should be taken into consideration for assessment of service impact on company's turnover (e.g. type of costumer served, seasonality, and promotion). Further research is necessary to assess the experience and challenges of companies with focus on one industry (i.e. the manufacture of fabricated metal products) and to consider different challenges in measuring impact of services provided by manufacturing companies. Development of these ideas could prove, especially useful to firms facing the challenges of such industry, specific services to improve their financial performance [20]. It is foreseen to conduct this type of research again over a certain period, as EMS is a survey 
which is carried out on a triennial basis. In this way, we will be able to measure to what extent introduction of services affect turnover of manufacturing companies over time. In addition, next EMS survey should include "smart services" which are offered based on ICT functionalities of the product. In this manner, research results could reveal the possible strategy for emerging economies to take a lead and get closer to to developed countries.

\section{Acknowledgement}

This work is supported by funding of Croatian Science Foundation O-1861-2014 3535 Building competitiveness of Croatian Manufacturing.

\section{References}

1. Vandermerwe S., Rada J.: Servitization of business: Adding value by adding services. European Management Journal 6(4), 314-324 (1988).

2. Shimomura Y., Nemoto Y., Ishii T., Nakamura T.: A method for identifying customer orientations and requirements for product-service systems design. International Journal of Production Research 56(7), 2585-2595 (2017).

3. Dachs B., Biege S., Borowiecki M., Lay G., Jäger A., Schartinger D.: Servitisation of European manufacturing: empirical evidence from a large-scale database. Service Industries Journal 34(1), 5-23 (2014).

4. Lay G., Copani G., Jäger A., Biege S.: The relevance of service in European manufacturing industries. Journal of Service Management 21(5), 715-726 (2010).

5. Santamaría L., Jesús Nieto M., Miles I.: Service innovation in manufacturing firms: Evidence from Spain. Technovation 32(2), 144-155 (2012).

6. Crozet M., Milet E.: Should everybody be in services? The effect of servitization on manufacturing firm performance. Journal of Economics \& Management Strategy 26(4), 820-841 (2017).

7. Kinkel S., Kirner E., Armbruster H., Jager A.: Relevance and innovation of productionrelated services in manufacturing industry. International Journal of Technology Management 55(3-4), 263-273 (2011).

8. Kowalkowski C., Gebauer H., Oliva R.: Service growth in product firms: Past, present, and future. Industrial Marketing Management 60, 82-88 (2017).

9. Johnstone S., Wilkinson A., Dainty A.: Reconceptualizing the Service Paradox in Engineering Companies: Is HR a Missing Link? IEEE Transactions on Engineering Management 61(2), 275-284 (2014).

10. Kowalkowski C., Kindström D., Alejandro T. B., Brege S., Biggemann S.: Service infusion as agile incrementalism in action. Journal of Business Research 65(6), 765-772 (2012).

11. Gao J., Yao Y., Zhu V. C. Y., Sun L., Lin L.: Service-oriented manufacturing: a new product pattern and manufacturing paradigm. Journal of Intelligent Manufacturing 22(3), 435-446 (2011).

12. Oliva R., Kallenberg R.: Managing the transition from products to services. International Journal of Service Industry Management 14(2), 160-172 (2003). 
13. Luoto S., Brax S. A., Kohtamäki M.: Critical meta-analysis of servitization research: Constructing a model-narrative to reveal paradigmatic assumptions. Industrial Marketing Management 60, 89-100 (2017).

14. Tukker A.: Eight Types of Product - Service System: Eight Ways To Sustainability?. Business Strategy and the Environment 260, 246-260 (2004).

15. Dachs B., Biege S., Borowiecki M., Lay G., Jäger A., Schartinger D.: Servitisation of European manufacturing: evidence from a large scale database. Service Industries Journal 34(1), 5-23 (2014).

16. Lalic B., Majstorovic V., Marjanovic U., Delić M., Tasic N.: The Effect of Industry 4.0 Concepts and E-learning on Manufacturing Firm Performance: Evidence from Transitional Economy. Lödding, H., Riedel, R., Thoben, K.-D., von Cieminski, G., Kiritsis, D. (Eds.) IFIP WG 5.7 International Conference, APMS 2017, Advances in Production Management Systems. The Path to Intelligent, Collaborative and Sustainable Manufacturing, vol. 513, pp. 298-305, Springer International Publishing AG (2017).

17. Lalic B., Medic N., Delic M., Tasic N., Marjanovic U.: Open Innovation in Developing Regions: An Empirical Analysis across Manufacturing Companies. International Journal of Industrial Engineering and Management 8(3), 111-120 (2017).

18. Lalic B., Anisic Z., Medic N., Tasic N., Marjanovic U.: The impact of organizational innovation concepts on new products and related services. In: Proceedings of $24^{\text {th }}$ International Conference on Production Research - ICPR, pp. 110-115, DEStech Publications, Inc., Poznan, Poland (2017).

19. Gebauer H., Fleisch E., Friedli T.: Overcoming the service paradox in manufacturing companies. European Management Journal 23(1), 14-26 (2005).

20. Visnjic Kastalli I., Van Looy B.: Servitization: Disentangling the impact of service business model innovation on manufacturing firm performance. Journal of Operations Management 31(4), 169-180 (2013). 